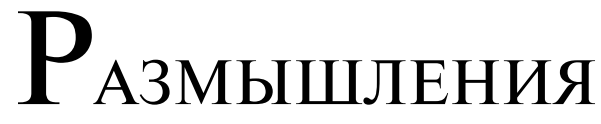 НА ЗАДАННУЮ ТЕМУ
}

\section{Reflections ON A GIVEN THEME}

\section{МОВА ЯК З' ЯВА: \\ БЕАОРУССКИЙ ЯЗЫК В КОНТЕКСТЕ АИГАОССИИ}

\author{
М. А. МОЖЕЙКо ${ }^{1)}$ \\ 1) Белорусский государственный университет культуры и искусств, \\ ул. Рабкоровская, 17, 220007, г. Минск, Беларусь
}

О языке можно говорить с точки зрения языковеда, но язык - это еще и социокультурный феномен, и его развитие протекает в социальном и политическом контексте. Это, разумеется, относится к любому из языков, однако применительно к языку белорусскому данный факт обретает многие специфические аспекты. Прежде всего это касается ситуации билингвизма (причем билингвизма близкородственного), в рамках которого под влиянием социально-политических факторов языки обретают неэквивалентные статусы, в результате чего выстраивается их иерархия. Историческое развитие белорусского языка (в его контекстном соотношении с русским) демонстрирует серьезные деформации, которые ему пришлось пережить в ходе своей эволюции.

Ключевые слова: белорусский язык; языковая вариативность; социальные роли языка; вертикальный билингвизм; диглоссия; статус языков; H-язык (high language); L-язык (low language); языковая иерархия; экзоглоссность.

Образец цитирования:

Можейко МА. Мова як з'ява: белорусский язык в контексте диглоссии. Журнал Белорусского государственного университета. Социология. 2020;4:79-92.

https://doi.org/10.33581/2521-6821-2020-4-79-92

\section{For citation:}

Mojeiko MA. Language as a phenomenon: Belarusian language in the context of diglossia. Journal of the Belarusian State University. Sociology. 2020;4:79-92. Russian. https://doi.org/10.33581/2521-6821-2020-4-79-92

\section{Ав тор:}

Марина Александровна Можейко - доктор философских наук, профессор; заведующий кафедрой философии и методологии гуманитарных наук факультета культурологии и социокультурной деятельности.

\section{Author:}

Marina A. Mojeiko, doctor of science (philosophy), full professor; head of the department of philosophy and methodology of humanities, faculty of culturology and sociocultural activities. marina-mojeiko@yandex.by 


\title{
LANGUAGE AS A PHENOMENON: BELARUSIAN LANGUAGE IN THE CONTEXT OF DIGLOSSIA
}

\author{
M. A. MOJEIKO \\ ${ }^{\mathrm{a}}$ Belarusian State University of Culture and Arts, \\ 17 Rabkaraŭskaja Street, Minsk 220007, Belarus
}

It is possible to talk about language from the point of view of a linguist, but language is also a sociocultural phenomenon, and its development takes place in a social and political context. This, of course, applies to any of the languages, however, in relation to the Belarusian language it acquires many specific aspects. First of all, this concerns the situation of bilingualism (and bilingualism as closely related), within which, under the influence of socio-political factors, languages acquire unequal status, as a result of which their hierarchy is built. The historical development of the Belarusian language (in its contextual relationship with Russian) demonstrates serious deformations that it had to endure in the course of its evolution.

Keywords: Belarusian language; linguistic variability; social roles of language; vertical bilingualism; diglossia; status of languages; H-language (high language); L-language (low language); language hierarchy; exoglossity.

\begin{abstract}
...Сколько бы мы ни усердствовали на пути истребления в душах человеческих разных социальных учреждений, мы никак не можем вытравить из них языка. Язык остается, несмотря на все гонения и противодействия, язык остается при любой форме правления, при любом устройстве общественной и хозяйственной жизни.
\end{abstract}

И. А. Бодуэн де Куртенэ
В силу многоплановой дифференцированности языков перед говорящим субъектом в любой языковой коммуникации открывается возможность вариантов его использования, потому неизменно возникает ситуация выбора между литературным языком и просторечием, профессиональным или иными арго, любыми из диалектов и т. п.

В условиях двуязычия речевая вариативность обретает дополнительное измерение: билингв выбирает еще и между двумя национальными языками, в силу чего под воздействием внеязыковых факторов возможно формирование диглоссии ${ }^{1}$. По определению Дж. Эдвардса, под диглоссией понимают особый тип билингвизма (причем поддержанный специальной языковой политикой), при котором оба языка образуют единую социально-коммуникативную систему и находятся в отношениях функциональной дополнительности, имея при этом не совпадающие сферы применения и разный социальный статус [1, p. 20-21]. Последнее принципиально важно: диглоссия формируется только при вертикальном и асимметричном варианте билингвизма, т. е. в ситуации диглоссии сосуществование двух языков в рамках одного сообщества предполагает их использование в принципиально различных социальных ситуациях и коммуникативных средах. Так, К. Бакер отмечает, что «на практике языковое сообщество... чаще использует один язык в определенных ситуациях и для определенных функций, другой язык - в иных обстоятельствах и для иных функций. Например, языковое сообщество может использовать язык меньшинства для общения внутри семьи, при отправлении религиозного культа и в общественной деятельности этого меньшинства, а язык большинства - на работе, в образовании и в средствах массовой информации» ${ }^{2}[2$, p. 44].

В. М. Жирмунский усматривал различие между такими языками «в их социальной функции» [3, с. 16]. По оценке филологов, существуют «вполне объективные критерии общественной роли данного языка, его функционирования в различных сферах государственной, общественной, культурной жизни данного общества» и иногда «распределение

\footnotetext{
${ }^{1}$ Не следует путать диглоссию с двуязычием: индивидуальный билингвизм - способность субъекта говорить на двух языках; билингвизм языковой ситуации в стране или регионе - наличие двух языков в речевой практике сообщества. Важно, однако, что факт наличия билингвизма необходим, но не достаточен для формирования диглоссии, т. е. далеко не всегда и не всякая двуязычная ситуация порождает диглоссию. Но это отдельная тема.

${ }^{2}$ Здесь и далее перевод наш. - M. M.
} 
подобных функций между разными языками по меньшей мере неоднозначно» [4, с. 15].

В перспективе такая языковая ситуация может привести к аксиологически окрашенным деформациям, в силу которых языки обретают различный статус. Дж. Хетцлер говорит о горизонтальном и вертикальном членении языка [5, p. 308]. По формулировке У. Вайнрайха ${ }^{3}$, в рамках диглоссии обретение языком того или иного социального статуса - процесс, детерминируемый большим количеством внеязыковых факторов, «на основании которых один из двух языков может определяться как “доминирующий”» [6, с. 136]. М. Н. Петерсон говорит в сходном контексте о специальных языках, которые возникают столь же естественно, как и территориальные диалекты, однако «различие заключается только в том, что они существуют не один около другого, как диалекты $^{4}$, а один над другим» [7, с. 14]. Таким образом, для диглоссии характерно сугубо вертикальное соотношение языков - их, как это называет У. Хадсон, функциональная иерархия [8, p. 109].

Филологи подмечали это обстоятельство еще в начале XX в. Так, И. А. Бодуэн де Куртенэ в числе факторов языкового развития упоминает «сознательное вмешательство административных властей и других политических и общественных факторов, прибегающих к разным предохранительным и принудительным мерам» [9, с. 367]. Это влияние осуществляется через образование и церковь «под влиянием школы и проповеди» [9, с. 369]. Кроме того, по мнению ученого, «нельзя... отрицать влияния... чужого официального или приказного языка, военной службы в армиях, состоящих из чужеязычных элементов или с командою чужеязычной» $[10$, с. 92].

Осуществляя историческую реконструкцию эволюции немецкого языка, В. М. Жирмунский отмечает, что язык, на котором немецкий крестьянин говорит дома (вариант «местного крестьянского говора»), не совпадает с тем языком, с которым он «знакомится в школе, который преподносится ему в печати, который он сам употребляет, - обычно в форме, более или менее окрашенной местным диалектом, - в общении с “высшими”, т. е. представителями господствующих классов, и вообще в тор- жественных и официальных случаях жизни. С точки зрения такого крестьянина, язык господствующего класса представляет более “высокую” и более “правильную” форму национального языка» ${ }^{5}$ [3, с. 16].

На основе понятия диглоссии создатель Центра прикладной лингвистики (Вашингтон, округ Колумбия) Ч. А. Фергюсон ${ }^{6}$ предложил модель вариантов билингвизма [11, p. 325-340; 12, с. 122-127]. Она разработана на материале языков Азии (в частности, Индии [13, p. 22-59]), но обладает универсальным инструментарием.

Ч. А. Фергюсон фиксирует в ситуации диглоссии два возможных (но не совозможных, полностью взаимоисключающих друг друга) статуса того или иного языка: каждый из двух языков может обретать статус либо $H$-языка (high language), либо $L$-языка (low language). Разница в сферах применения: $H$-язык используется в так называемых высоких, небытовых сферах книжно-письменной культуры (в официальных документах, вербальных видах искусства, в религии, науке, системе образования), в то время как $L$-язык - в так называемых низких, бытовых сферах номинации и коммуникации, в низких жанрах художественной культуры и т. п. [11, p. 325-340; 12, c. $122-127 ; 13$, p. 22-59].

Например, диглоссия характерна для большинства арабских стран: единый литературный язык арабов, восходящий к классическому арабскому языку VII в., имеет только письменную форму выражения. Это язык Корана, книжно-письменной культуры, науки, публицистики, официально-деловой документации, высшего и отчасти среднего образования. Однако им владеют только 25-30 \% арабского населения. «В повседневном общении, в неофициальных программах радио и телевидения, в начальной школе используются многочисленные и далеко разошедшиеся диалекты арабского языка - алжирский, египетский, иракский, йеменский» $[14$, с. 108].

Феномен диглоссии может осложняться и дополнительными социокультурными факторами: например, в неарабских, но при этом исламских странах Африки «диглоссия культового арабского и местных африканских языков сочетается с многоязычием, которое образуется двумя-тремя местны-

\footnotetext{
${ }^{3}$ Выдающийся американский лингвист, один из основателей социолингвистики. Родился в Вильно, его дед по матери известный еврейский врач и общественный деятель Цемах Шабад - выступил для К. И. Чуковского прототипом доброго доктора Айболита (см.: Чуковский К. И. Как я написал сказку «Доктор Айболит» [Электронный ресурс]. 2012 URL: https:// web.archive.org/web/20120514102906/http://www.chukfamily.ru/Kornei/Prosa/aibolit.htm (дата обращения: 21.07.2020)).

${ }^{4}$ Социолекты также сосуществуют параллельно: даже если один из них более престижен, нежели другой, тем не менее доминирования не происходит: язык аристократов или политической элиты не становится (и не стремится становиться) языком, например, носителей сельской или молодежной культуры.

${ }^{5}$ В этом контексте В. М. Жирмунский делает одно любопытное (и воистину забавное) наблюдение, обращая внимание на то, как сугубо топографический смысл слова Ноch обретает аксиологическое значение: «Слово “Hоchdeutsch", сперва обозначавшее “верхненемецкий” в противоположность “нижненемецкому”, т. е. диалектам северно-немецкой низменности (“Niederdeutsch”), приобретает в этой связи оттенок более “высокой” речи, свойственной представителям “высших", т. е. господствующих классов» [3, с. 16].

${ }^{6}$ См.: Our Founder: Charles Albert Ferguson, PhD // CAL: Center for Applied Linguistic [Electronic resource]. URL: http://www. cal.org/who-we-are/our-founder (date of access: 30.06.2020).
} 
ми языками и европейским языком (французским или английским) - в качестве официального государственного языка и языка межэтнических контак тов» $[14$, с. 108$]$.

С другой стороны, диглоссия может оформляться даже в рамках фактически одного национального языка, когда разные его подсистемы имеют различный статус в культуре [15, с. 468-474]. Например, в допетровской России статус $H$-языка имел церковнославянский язык по сравнению с разговорным русским как $L$-языком ${ }^{7}$ [16, с. 271-309]. Причем дивергенция в подобных случаях может заходить чрезвычайно далеко - вплоть до необходимости перевода: так, в XVI в. был создан анонимный рукописный словарь для переводов «Лексисъ съ толкованіемъ словенскіхъ мовъ просто» [18; 19, с. 300-301].

Однако дифференциация языков, в разной степени высоких, может создавать и более сложные конфигурации, причем далеко не в каждом случае это приводит к диглоссии (например, высокая, книжная и державная речь в современной Норвегии ${ }^{8}$ ).

В любом случае каждый вариант языка имеет свою сферу использования, т. е. «область внеязыковой действительности, характеризующуюся относительной однородностью коммуникативных потребностей, для удовлетворения которых говорящие осуществляют определенный отбор языковых средств и правил их сочетания друг с другом» [23, с. 59]. И важным аспектом диглоссии является «сознательный выбор говорящего между разными коммуникативными средствами и использование такого средства, которое наилучшим образом способно обеспечить успех коммуникации в данной сфере общения» [24, с. 60].

При таком ракурсе рассмотрения на передний план выступает исследование корреляций между языковой практикой и социальными характеристиками носителя языка (внеязыковой статус говорящего, набор и диапазон реализуемых им социальных ролей и т. п.). В этом контексте возникает вопрос о критериях применения говорящим того или иного языка (из возможного диапазона выбора) в каждой коммуникативной ситуации [25].

Разумеется, в соответствии с диглоссной дифференциацией языков в ситуации вертикального и асимметричного двуязычия усугубляются и дифференциация престижности владения тем или иным языком, его социальная окрашенность и оценка окружающими его практикования, и эта аксиологическая установка закрепляется в массовом сознании соответствующего общества.

И если феноменологически на передний план могут выходить культурные маркеры престижности $H$-языка (религия, искусство и др. ${ }^{9}$ ), то ноуменально за данными феноменологическими (культурными) маркерами всегда стоят детерминанты социально-политического характера. По мнению Э. Хаугена, именно и только «политические и социальные факторы» приводят «к господствующему положению одного языка по отношению к другому», и «социальное господство одних языков над другими» вызвано «политическими условиями, информацию о которых мы можем почерпнуть только у исследователей политической истории народов» [26, с. 64].

Применительно к дисбалансу использования $H$-языка и $L$-языка это значит, что формирование такой дихотомии нельзя объяснить ни интралингвистическими, ни интракультурными факторами: оно становится понятным лишь при учете политической ситуации. Язык, как известно, может быть эффективным инструментом власти, в том числе

\footnotetext{
${ }^{7}$ Формирование универсального русского как письменного языка и языка официального быта (посредством интеграции «языковых элементов, характерных для самых разных уровней жанрово-иерархической структуры русского средневековья») пришлось только на вторую половину XVIII в. [16, с. 297-298; 17, с. 149-158].

${ }^{8}$ C III в. в Норвегии применялось рунические письмо; с приходом христиан появились латинские вкрапления; после заключения союза с Данией в 1397 г. в Норвегии доминировал датский вариант скандинавского языка; затем союз с Данией сменился на союз со Швецией, - в итоге всех этих пертурбаций началась борьба за независимость, национальную идентичность и национальный язык. На этой волне в XIX в. норвежский филолог и борец за независимость Ивар Осен осуществил разработку письменного норвежского языка (объездив все регионы Норвегии и обобщив все диалекты, результатом чего стала фундаментальная книга «Национальный язык»), благодаря чему и сформировался этот национальный язык - лансмол (норв. landsmål - язык страны). В современной Норвегии языковая ситуация предполагает две официальные формы письменного стандарта норвежского языка: 1) санкционированный официально в 1929 г. букмол (норв. bokmål - книжная речь), основанный на более традиционном и консервативном стандарте - puксмоле (норв. riksmål державная речь); 2) нюнорск (норв. nynorsk - новый норвежский), в прошлом известный как лансмол (название сменилось в том же 1929 г.). Букмол и нюнорск представляют соответственно консервативную и радикальную версии письменного норвежского языка; букмол чаще используется в городских и пригородных местностях, а нюнорск - в сельской. Кроме того, широко применяется (хотя и не закреплен официально) хёгнорск (норв. høgnorsk - высокий норвежский) - более радикальный, чем нюнорск, но не достигающий традиционности букмола. Норвежцы могут получать образование на любом из двух официальных языков - диглоссии не возникает; тем не менее в настоящее время имеется тенденция к объединению названных языков в общенорвежский - самнорск (норв. samnorsk - всенорвежский) [20, с. 300-327; 21$, c. $107-120 ; 22]$.

${ }_{9}$ На материале анализа немецкого языка В. М. Жирмунский делает тонкое наблюдение, наглядно демонстрирующее этот аспект диглоссии (хотя и работает в другой терминологии): он подмечает, что, имея в виду языковую норму, говорят о литературном языке (Literatursprache), письменном (Schriftsprache) и даже сценическом языке (Bühnendeutsch) «в расширенном значении национального языка» [3, с. 7].
} 
и средством имплицитного воздействия на сознание ${ }^{10}$.

Что касается регионов с пестрым ${ }^{11}$ этническим (соответственно, и языковым) составом населения, диглоссная ситуация обретает еще одно измерение: возникает, по оценке Ч. А. Фергюсона, феномен экзоглоссности: $H$-язык, не будучи родным для большинства носителей $L$-языков, обретает характер надэтнического языка [13; 34], и важным аспектом его доминирования выступает то обстоятельство, что он начинает использоваться универсально, при этом не являясь для большинства языком социализации ${ }^{12}[35$, с. 45$]$. Парадокс заключается в том, что носители $H$-языка могут быть монолингвами, в то время как носители $L$-языков нередко владеют несколькими языками. Классический пример - Британская империя имперского столетия (1815-1914): англоязычные сагибы (носители $H$-языка), как правило, были монолингвами.

А. Р. Диболд считает экзоглоссность неизбежным следствием диглоссии и усматривает в ней опасность для стабильности культурной идентичности, а именно неизбежный «кризис социальной и личностной идентичности, порожденный антагонистическим культурным давлением, направленным на бикультурное сообщество со стороны социально доминирующего моноязычного общества, внутри которого бикультурное сообщество подвергается стигматизации» [36, p. 85].

Это порождает ситуации языковой сегрегации (например, Дж. Камминс анализирует ситуации, когда «использование некоторого языка, отличного от английского, обрекает людей на гражданство второго сорта в американском обществе» [37, p. 60]).

В истории белорусского языка также имели место ситуации диглоссности.
Так, после вхождения белорусских земель в состав Российской империи, согласно наказу Екатерины II от 1772 г., касающемуся присоединенных земель, все официальное делопроизводство переводилось на русский язык. Губернской канцелярии было предписано: «...дела вы имеете производить на Российском языке, то есть все издаваемые от вас, какого бы звания ни были, приговоры, решения или повеления, присовокупляя к тому переводы, где оные нужны будут» ${ }^{13}$. Население имело право использовать родной язык лишь «в тех случаях, коие не дотрагиваются нашей власти» ${ }^{14}$, - классическая схема диглоссии ${ }^{15}$.

В этом контексте белорусский язык обретает статус $L$-языка, вытесняясь из официальных и высоких контекстов в сугубо бытовую сферу. Тем самым «у беларускай мовы не было ніякіх шанцаў хоць трохі наблізіцца да мовы дзяржаўнай, увайсці ў афіцыйны ўжытак», - фактически «змена польскага гаспадара рускім ніколькі не мяняла сацыяльнага становішча роднай мовы беларусаў» [39, с. 54].

Не поменяло ситуации и вхождение белорусской республики в СССР: в современном «Словаре социолингвистических терминов» русификация определяется как «политика царской и советской России, направленная на языковую ассимиляцию иноязычного населения» [24, с. 189] - без усмотрения различий в этих вариантах языковой политики.

Действительно, в советский период в паре языков русский - белорусский наблюдалась ситуация достаточно острой диглоссии. Русский язык имел статус $H$-языка и санкционированно использовался в официальных контекстах. Белорусский язык в этой ситуации занимал $L$-статус - со всеми вытекающими отсюда последствиями. Более того, в рамках концепции единой исторической

\footnotetext{
${ }^{10}$ Разумеется, это не зависит от наличия/отсутствия ситуации билингвизма: язык как таковой идеологичен в самом широком смысле этого слова [27; 28]. И не только в том плане, что идеология проницает собой все культурное пространство [29-31], - язык идеологичен по самой своей глубинной природе. Как отмечает Дж. Марин-Аррес, в любом случае «говорящий/пишущий стремится контролировать ход самой реальности или влиять на него», и для этого у него есть множество языковых инструментов: «...ценочное позиционирование... деонтичность, направленность и выражение желательности, интенциональность, нормативность и т. п.» [32, p. 105]. Для убедительности речевого акта значение имеет даже порядок слов в предложении, а в результате частого использования того или иного слова в специфических контекстах могут происходить, как отмечает С. Лестрейд, его «десемантизация» и «эрозия смысла» [33, p. 92].

${ }^{11}$ Конечно, пестрота имеет свои количественные параметры, и важно, что начинается она там, где больше одного этноса (и, соответственно, больше одного языка). Безусловно, чем языков больше, тем ситуация выразительнее, но для выстраивания вертикали достаточно и двух.

${ }^{12} \mathrm{~B}$ этом принципиальное отличие экзоглоссности $H$-языка от наддиалоговых языков (ситуативно возникающих устных языков-посредников при цивилизационных контактах): взаимодействие языков при формировании последних протекает как горизонтальное, и наддиалоговый язык не конституируется как надэтничный, поскольку нет субъекта-носителя, чьи притязания это могло бы выражать, - феномен экзоглоссности не возникает (наддиалоговые языки вообще не могут рассматриваться в рамках дихотомии $H$-языка и $L$-языков). Сравним также с приведенным выше описанием ситуации с вариантами норвежского: при дифференциации сфер применения все они тем не менее выступают версиями одного и того же национального языка, так что ни один из вариантов не является надэтничным и ситуация не оформляется как экзоглоссная.

${ }^{13}$ Императрицы Екатерины II Наказ, по которому на первый случай поступать господам Генералам Майорам Каховскому и Кречетникову в отправлении должностей Губернатора в Губернии Псковской и Могилевской // Полное собрание законов Российской империи. Собрание первое: с 1649 по 12 декабря 1825 года. Т. 19. 1770-1774. СПб, 1830. С. 510.

${ }^{14}$ Там же. С. 509.

${ }^{15}$ Ситуация усугублялась также и наличием латиницы: как было отмечено И. Ю. Лёсиком (Язэп Лёсік) еще на знаменитой языковой конференции 1926 г., «у тыя часы Масква баялася лаціншчыны і скрыва пазірала на Літву (Беларусь), адкуль падчас трапляла да Масквы гэтая “латынь” у форме розных кніжак “проклятой литовской печати”» [38, с. 117].
} 
общности - советского народа - русский язык выступал с позиций надэтничного (как и в отношении других национальных языков народов СССР), что создавало ситуацию очевидной экзоглоссности.

В советских изданиях, разумеется, трактовка была иной. Например, В. А. Виноградов, справедливо приводя в качестве примера диглоссной языковой ситуации страны Магриба, не усматривает аналогичных процессов в советских республиках, где якобы «функционально сосуществуют национальный и русский языки» [40].

Более того, двуязычие как таковое рассматривалось в советском языкознании как временное явление, характерное лишь для переходного этапа от социализма к коммунизму. Например, в описании В. А. Аврорина: «...если иметь в виду всю историю человечества от самого ее начала до предвидимой нами вершины социального прогресса, есть все основания считать двуязычие лишь переходным моментом... в конечном счете неизбежно обреченным на окончательное устранение» [41, с. 136].

Однако если речь шла об усвоении русского языка как экзоглоссного, то позиция резко менялась: «...если же иметь в виду нашу современность как определенную историческую эпоху, то придется признать, что социальная ценность двуязычия во все большей и большей степени, особенно в социалистических странах, возрастает» [41, с. 136].

Все это вписывалось еще и в теорию Н. Я. Марра, которую он сам называл новым учением о языке и согласно которой развитие языков имеет классовую природу. Высказанная в конце 1920-х гг., эта псевдонаучная теория пользовалась в Советском Союзе государственной поддержкой вплоть до 1950-х гг.; вред от теории Н. Я. Марра для лингвистики традиционно сравнивают с ущербом, нанесенным лысенковщиной в области биологии [42]. В рамках этой теории также педалировался тезис о грядущем всемирном языке, и в 1926 г. в возглавляемом Н. Я. Марром Яфетическом институте планировалось даже создание группы, которая бы «имела заданием “установление теоретических норм” будущего общечеловеческого языка, проблема которого... включена была с самого начала в план работы института» [43, с. 258].

Теория социалистического строительства откровенно сдвигала языковую ситуацию в союзных республиках в сторону экзоглоссной диглоссии, а национальные языки - к статусу $L$-языков, ограниченных с точки зрения возможных сфер применения: «...в нашей стране сейчас все народы, как можно думать, ощущают несомненную пользу от двуязычия и не видят в нем никакой помехи для своего дальнейшего развития, для укрепления дружбы с другими народами. Перед ними не возникает задачи отказа от одного из языков. Проблема совсем в другом - в разумном распределении сфер употре- бления между взаимодействующими языками. <...> По необходимости родной язык здесь ограничивается рамками семейного и производственно-бытового общения, а также устного художественного творчества, т. е. применением в сферах немногочисленных, хотя и занимающих большое место в повседневной жизни народа. Прочие среды и сферы, которых значительно больше, обслуживаются, как правило, вторым языком - языком межнационального общения». [41, с. 137]. Ни убавить, ни прибавить: можно использовать прямо как дефиницию экзоглоссной диглоссности.

Сложившаяся система доминирования русского как $H$-языка над другими национальными языками открыто объявлялась оптимальной: «...советский опыт культурно-языкового строительства убедительно показал отсутствие социально обусловленной потребности выравнивания уровня функционального развития всех без исключения языков народов СССР» [44, с. 17].

Более того, диглоссия не только объективно существовала, но и объявлялась благом, в контексте чего русский язык как экзоглоссный наделялся некими мифическими функциями: «...русский язык в своем статусе средства межнационального общения не ограничивается ролью посредника между народами Советского Союза, но и является определенным фактором, стимулирующим творческий процесс и в области производства, и в области экономики, и в области культуры» [45, с. 4].

Подобных публикаций - монбланы, и позиция всех советских авторов одна. Согласно утверждениям некоторых авторов, «не Сталин, а именно Хрущев, всерьез веривший в “стирание различий”, включая языковые, на пути к коммунизму, был самым активным проводником политики русификации в советское время» [46, с. 213-214]. Но персонификация инициатора этой политики не так уж и принципиальна: три приведенных в качестве примера советских публикации датируются 1975, 1982 и (sic!) 1990 гг.

Филология даже не стала ареной классовой борьбы: все было четко определено, намертво утверждено и строго ограничено.

Фактически эти исторические деформации социального статуса белорусского языка и отмечает А. И. Мальдис, говоря об исторических трудностях его развития: «Забароненая ў афіцыйных сферах, пазбаўленая “высокіх жанраў”, літаратура, нібы тая рака, перагароджаная штучнай плацінай, знаходзіла абходныя шляхі, прасочвалася ў народны “грунт”, фалькларызавалася» [47, с. 336].

Принципиально важным критерием демаркации $H$ - и $L$-языков выступает организация системы образования. Особенно резко это проявляется в условиях экзоглоссности: $H$-язык, как надэтничный, тотально фундирует собой образовательную среду, 
а национальные $L$-языки полиэтничного диглоссного общества остаются за пределами образовательных процедур.

Практическим следствием этого обстоятельства является тот факт, что, по формулировке В. М. Жирмунского, именно на надэтническом языке (в терминологии Ч. А. Фергюсона - H-языке) «ведется преподавание в школах разного типа, и ему обучают как “родному языку” даже там, где фактически родным языком детей является местный диалект» (в терминологии Ч. А. Фергюсона, - один из L-языков) [3, с. 7].

Так было и на белорусских землях в пору их бытности в составе Российской империи. Кастусь Калиновский в «Пісьмах 3-пад шыбеніцы» писал об имперской языковой политике: «...там, гдзе жылі палякі, літоўцы і беларусы, заводзіць маскоўскія школы, а ў гэтых школах учаць па-маскоўску, гдзе ніколі не пачуеш і слова па-польску, па-літоўску да i па-беларуску, як народ таго хочэ» ${ }^{16}$.

Так было и в советской школе, где, как правило, уроки русского языка велись каждый день, уроки национального - лишь один или два раза в неделю: в той же мере, как уроки иностранного (если не реже, как, например, в специализированных школах, где ряд предметов преподавали по-английски).

Такая ситуация, естественно, не может не обретать эмоциональную размерность: еще в конце XIX в. О. Бехагель, описывая подобные ситуации, использовал очень точный термин язык других [48, p. 182].

И, разумеется, это негативно сказывается на объективном развитии $L$-языков: мало того, что спектр их применения сужается еще больше, вымываясь из сферы образования (тем самым нарушаются также естественные механизмы их трансляции от поколения к поколению), но и явление естественной взаимной интерференции языковых элементов обретает насильственный и травмирующий характер (оценивая влияние языковой политики Российской империи в отношении белорусского языка, А. Балицкий в 1925 г. писал: «...мова дзяцей калечылася» $[49$, с. 117]).

При этом общественные условия могут складываться таким образом, что, согласно утверждению У. Вайнрайха, «овладение определенным языком приобретает для индивида большое значение не только из-за необходимости иметь новое средство общения, но и потому, что этот язык является средством, способствующим продвижению в обществе» [6, с. 135]. Например, Г. К. Баркер, определяя социальные функции языков в контексте диглоссии [50; 51], описывает ситуацию в Таксоне (штат Аризона), в рамках которой выходцы из Латинской Америки для того, «чтобы улучшить свои отношения с Anglos (одноязычными лицами, говорящими на англий- ском), могут даже отрицать, что знают испанский язык» [52]. В Швейцарии, по оценке У. Вайнрайха, «французский язык охотно изучался на территории местного диалекта как ценное средство в приобретении более высокого социального положения. Иногда условия для продвижения в обществе могут даже требовать явного игнорирования другого языка, который для данного лица может быть родным» [6, с. 135]. Аналогично использование национального языка в любой из советских республик не давало тех возможностей социальной самореализации, которые открывали русскоязычные коммуникации. Как отмечает А. А. Сомин, «послевоенная урбанизация, статус русского языка и возможности, которые предоставляло владение им, - все это повлияло на падение престижа белорусского языка и стремление перейти на русский» [53, с. 65].

Разумеется, это не может не отражаться на реальной речевой практике.

Именно поэтому Дж. Эдвардс определяет диглоссию как языковую ситуацию, которая, с одной стороны, изначально неравноправна, с другой это неравноправие усугубляется в ходе исторической динамики, и один из языков (разумеется, это $H$-язык) обычно берет верх [1]. И, безусловно, как отмечает Э. Хауген, в любом прецеденте языкового доминирования исчезновение угрожает именно языкам политически зависимых групп [26].

Так что - с учетом таких перспектив - доминирование $H$-языка в условиях экзоглоссности для $L$-языков далеко не безобидно.

И что касается в свете сказанного динамики экзоглоссной ситуации, то в отношении ее выделяют два возможных вектора развития, причем оба не являются объективно-спонтанными (естественноисторическими): так, в целях предотвращения разрушения историко-культурной среды может культивироваться тенденция к архаизации, а в целях смены или преобразования культурной принадлежности - в сторону ксенизации [54, с. 57].

Особенно опасна надэтничная (экзоглоссная) диглоссия при ее наложении на близкородственный билингвизм: в этом случае вероятность дивергенции (именно из-за близкородственности) минимальна, если не сводится к нулю: вымывание $L$-языка из практики становится грозной перспективой, избежать которой можно только сознательным целенаправленным усилием коллективного субъекта (носителей $L$-языка).

Как полагает Дж. Эдвардс, в условиях, когда в диглоссии задействованы близкородственные языковые элементы, она имеет тенденцию к постепенному исчезновению: $H$-язык вытесняет $L$-язык [1].

Ряд авторов утверждают, что в разворачивании экзоглоссности накладываются друг на друга

\footnotetext{
${ }^{16}$ Каліноўскі К. Пісьмы з-пад шыбеніцы. Ліст першы // Беларуская палічка: беларуская электронная бібліятэка. URL: https://knihi.com/Kastus_Kalinouski/Pismy_z-pad_sybienicy.html (дата звароту: 23.07.2020).
} 
различные факторы, в том числе и объективные: так, например, говоря о языковой ситуации в России начала XX в., В. М. Алпатов пишет о том, что бурное развитие рыночных отношений в большинстве случаев стихийно усиливали роль русского языка, все более оттесняя малые языки в бытовую сферу [46, с. 210-219]. Однако в описанной ситуации объективны лишь необходимость наддиалогового языка, обеспечивающего коммуникацию, и отсутствие у коммуникантов знания третьего, нейтрального по отношению к ним языка (т. е. почему бы этому взаимодействию не осуществляться, например, по-английски?) - при унаследованном всеми постсоветскими странами и на начало XX в. еще инструментальном ${ }^{17}$ знании русского языка ${ }^{18}$.

Использование наддиалогового языка или какого-либо языка в кросс-культурных коммуникациях не результат злонамеренных действий темных сил, но процесс естественный и объективный: это только военные действия ведутся языком пушек, а дипломатия, торговля и сотрудничество требуют взаимопонимания (философия, кстати, еще в Средние века использовала в таком качестве латынь). Однако практикование языка международного общения отнюдь не всегда приводит (и не должно приводить!) к диглоссии и тем более экзоглоссности: подписание двустороннего коммюнике по-английски (точно так же как если швед и француженка где-нибудь в Греции или Грузии поговорят между собою поитальянски) еще не значит деформации и изменения статуса национальных языков.

Что же касается диглоссных и экзоглоссных ситуаций, то они без социально-политического нажима - сами собой - не возникают. Это, безусловно, продукт языковой политики. И, разумеется, большое значение имеет бэкграунд: историческая традиция взаимодействия языков влияет на ситуацию сегодняшнего дня, это влияние может быть весьма острым и от него никак не отмахнуться: в предыдущем примере можно было бы написать про казаха и украинку, говорящих в Египте по-русски (и вроде бы что плохого: открылась возможность пообщаться), но как-то не написалось.

Если же говорить о сохранении языков, которые имели несчастье в диглоссной ситуации оказаться в $L$-статусе, то здесь объективные закономерности никак не спасут: чтобы вернуть языкам, загнанным в $L$-статус, эволюционные перспективы, преодолеть последствия диглоссии и экзоглоссности, безусловно, нужны сознательные и целенаправленные усилия.

О необходимости таких усилий Л. В. Щерба писал еще в первой половине XX в.: изучение языка межнационального общения необходимо, но чтобы «он не был в ущерб» родному, «об этом следует позаботиться», а именно: «грамматики разных национальных языков в пределах Союза [ССР] должны прежде всего сбросить с себя иго русской грамматики. Грамматика и словарь каждого языка должны быть составлены совершенно независимо от других языков и вовсе не должны представлять из себя сколка с латинской, немецкой, русской грамматики или словаря. Каждый язык должно рассматривать как нечто вполне самодовлеющее» [62, с. 318].

Таким образом, сохранение языка в условиях диглоссии возможно лишь как результат конкретной и последовательной активности. Это касается любых исторических конфигураций и любых языков. Как показывает Э. Хауген на примере франкоязычного населения Канады, «только благодаря упорному сопротивлению в области культуры им удавалось противостоять этой тенденции», И «за объяснением такого сопротивления (или его отсутствия) мы можем обратиться к работам социологов» [26, с. 64].

Связывая проблему кодификации национальных языков с политическими событиями (Война за независимость США, Великая французская революция и др.), Э. Хауген отмечает, что в контексте социально-политических процессов «некоторые группы населения вдруг осознали, что их вынуждают говорить на каком-то новом языке и что они фактически являются гражданами второго сорта в своей собственной стране» [63, с. 454]. И. А. Бодуэн де Куртенэ писал: «Дорого право человека оставаться при своем языке, выбирать его себе, право не подвергаться отчуждению от всесторонней употребляемости собственного языка, право людей свободно самоопределяться и группироваться, тоже на основе языка» [64, с. 145$]$.

Соответственно, национальный язык, согласно мнению Дж. А. Фишмана, М. Х. Гертнера и др., играет важнейшую роль в национальном возрождении [65, p. 105-302].

В новоевропейской истории «политические катаклизмы вели к возникновению новых наций или к возрождению старых, - и мы видим, как в одной

\footnotetext{
${ }^{17}$ Для поколения $X$ - да, для миллениалов - поколения пехt, или поколения $Y$, - это уже далеко не везде так.

${ }^{18}$ Сегодня статус русского языка в каждой постсоветской стране моделируется по-разному. Например, в Республике Казахстан в качестве одной из задач общекультурного и профессионального образования выдвигается формирование многоязычного индивида, т. е. подготовка граждан, способных эффективно общаться на родном, государственном и межнациональном языках: казахский храним, русский используем, английский учим [55-57], - при планомерном разворачивании казахизации [58-61] - национальной политики, ориентированной на продвижение национальных руководящих кадров и культивирования языковой практики на национальном языке (своего рода аналог коренизации в республиках в первые годы советской власти). На сегодня в Республике Казахстан достигнуто «расширение и укрепление социальнокоммуникативных функций государственного языка, сохранение общекультурных функций русского языка, развитие языков этнических групп» (см.: Государственная программа функционирования и развития языков на $2000-2010$ гг. // Казахстан. правда. 2001. 17 февр. С. 1). Существуют и иные сценарии, не отводящие русскому языку такого статуса.
} 
стране за другой утверждаются новые языки результат кодификаторских усилий отдельных лиц, правительственных комиссий или академий» [63, с. 454]. По оценке экспертов, в начале бурного ХX в. было создано около 50 новых литературных языков [66, с. 6].

Сложившиеся языки в период социальных катаклизмов тоже находятся в центре внимания. Вспомним, например, активное обсуждение языковых проблем в Беларуси в 1920-х гг., знаменитую академическую конференцию 1926 г., масштабное проекты языковых реформ [67], - пока верилось в светлое будущее и пока национальный подъем не был насильственно свернут извне.

Потому неудивительно, что процесс распада Coветского Союза начался с актуализации языкового вопроса: как пишет В. М. Алпатов, «в конце 80-х годов почти во всех союзных и автономных образованиях СССР развернулось движение за расширение функций малых языков, против русификации. Во многих случаях оно становилось первым этапом борьбы за отделение от России и формирование национальных государств» [46, с. 210]. Соответственно, и в социокультурном пространстве Беларуси конца 1980-х - начала 1990-х гг. языковая проблема обрела ощутимо политизированный характер.

Именно в периоды острых социальных противостояний актуализируется тенденция языкового пуризма (фр. purisme, от лат. purus - чистый), т. е. стремления очистить литературный язык от иноязычных заимствований ${ }^{19}$ [68, p. 65-76; 24, с. 176] (собственно, от всех проявлений внелитературной речи: диалектизмов, просторечий, элементов арго - тоже, но иноязычные заимствования воспринимаются наиболее остро и как связанные с диглоссией, и потому вычищаются особенно старательно и с идеологической подоплекой).

В этом контексте язык, как отмечает Э. Хауген, превращается в национальный символ, а кодификатор языка начинает восприниматься как национальный герой [63, с. 453].

Как не вспомнить в этом контексте сакральную

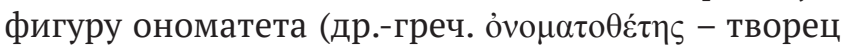

имен) в архаической мифологии (а затем - и в пифагореизме): тот, кто называет предметы внешнего мира [70, с. 88], - вариант культурного героя (герояцивилизатора), подобного Прометею. Фактически это тот, кто не просто открывает мир человеку, но практически творит для людей мир, доступный пониманию и адаптации в нем, - данный процесс сопоставим с креационным (собственно, в Ригведе он таковым и является), поскольку сакральность ономатета обусловливает в архаической картине мира онтологическую заданность имени самой сущностью предмета (прозревая сущность, он и дает единственно возможное для этого предмета имя).

Что касается национального самосознания, то для него это действительно именно так: как любое сознание объективируется в языке, так и любое национальное сознание нуждается в вербальном пространстве объективации. У. Вайнрайх так и рассматривал отношение народов к языку: как к «символу и орудию своего национального бытия» [71, с. 26]. Предисловие Ф. Богушевича к его сборнику «Дудка беларуская», которое традиционно считается манифестом белорусского национально-культурного возрождения, содержит трактовку языка как материализации души народа: «Пазнаюць людзей па гаворцы ці па адзежы, хто якую носіць; ото ж гаворка, язык і ёсць адзежа душы» ${ }^{20}$.

И если личное имя выступало в архаических культурах как сакральный идентификатор и оберег, то столь же фундаментальную роль для нации как субъекта играет национальный язык.

В частности, о белорусском языке А. А. Лукашанец пишет: «Нягледзячы на складанасці свайго развіцця... сучасная беларуская мова... па-ранейшаму застаецца сімвалам нацыянальнай свядомасці» [72, с. 4] и «нягледзячы на складанасці моўнага жыцця, асаблівасці развіцця сістэмы мовы і ступені запатрабаванасці ў камунікатыўнай прасторы, яна заўсёды была бадай што асноўным фактарам падтрымання нацыянальнай культуры і нацыянальнай свядомасці народа» [73, с. 3].

На этой оптимистической ноте...

\section{Библиографические ссылки}

1. Edwards J. Foundations of Bilingualism. In: Bhatia TK, Ritchie WC, editors. The handbook of bilingualism. Malden: Blackwell; 2006. p. 7-31.

2. Baker C. Foundations of bilingual education and bilingualism. Clevedon: Multilingual Matters Ltd.; 1993.492 p.

\footnotetext{
${ }^{19}$ Л. И. Скворцов отмечает, что «это связано с тем, что «пуризм характерен для времени становления национальных литературных языков, он проявляется также в периоды важных общественных событий (подъем демократического движения, революции, войны и т. п.) и связанных с ними значительных сдвигов в языке (главным образом в лексике), когда язык быстро и наглядно изменяется, вбирая много заимствований, неологизмов, стилистически перестраиваясь и т. п.» [69]. Я бы все же сказала, что внимание к национальному языку на волне национального подъема и борьба за его чистоту все-таки превалируют в этом процессе над фактором интенсивности его развития.

${ }^{20}$ Мацей Бурачок (Багушэвіч Ф.). Прадмова да зборніка «Дудка беларуская» // Беларуская літаратура ХІХ ст. : зб. тэкстаў / пад рэд. Я. Купалы. Мінск, 1940. С. 151.
} 

$304 \mathrm{c}$.

3. Жирмунский ВМ. Национальный язык и социальные диалекты. Ленинград: Художественная литература; 1936.

4. Ярцева ВН. Теория взаимодействия языков и работа У. Вайнрайха «Языковые контакты». В: Вайнрайх У. Языковые контакты. Состояние и проблемы исследования. Благовещенск: БГК имени И. А. Бодуэна де Куртенэ; 2000. c. $5-17$.

5. Hertzler JO. A Sociology o flanguage. New York: Random House; $1965.559 \mathrm{p}$.

6. Вайнрайх У. Языковые контакты. Состояние и проблемы исследования. Благовещенск: БГК им. И.А. Бодуэна де Куртэнэ; 2000. 264 с.

7. Петерсон МН. Язык как социальное явление. Ученые записки Института языка и литературы. 1927;1:3-21.

8. Hadson U. Diglossia. In: Spolsky B, editor. Concise encyclopaedia of educational linguistics. Oxford: Elsever Science Ltd.; 1999. p. 37-42.

9. Бодуэн де Куртенэ ИА. О смешанном характере всех языков. В: Бодуэн де Куртэнэ ИА. Избранные труды по общему языкознанию. Том 1. Москва: Издательство АН СССР; 1963. с. 362-372.

10. Бодуэн де Куртенэ ИА. Язык и языки. В: Бодуэн де Куртэнэ ИА. Избранные труды по общему языкознанию. Том 2. Москва: Издательство АН СССР; 1963. с. 67-95.

11. Ferguson ChA. Diglossia. World. 1959;15(2):325-340.

12. Фергюсон ЧА. Проблемы влияния языковой ситуации на обучение второму языку. В: Нерознак ВП, составитель; Гак ВГ, редактор. Новое в зарубежной лингвистике. Выпуск 25. Контрастивная лингвистика: переводы. Москва: Прогресс; 1989. с. 122-127.

13. Ferguson ChA. The phonems of Bengali. Language. 1962;36:22-59.

14. Мечковская НБ. Социальная лингвистика. Москва: Аспект Пресс; 1996. 207 с.

15. Крысин ЛП. Владение разными подсистемами языка как явление диглоссии. В: Крысин ЛП. Русское слово, свое и чужое. Исследования по современному русскому языку и социолингвистике. Москва: Языки славянской культуры; 2004. c. $468-474$.

16. Шапир МИ. Теория «церковнославянско-русской диглоссии» и ее сторонники. Russian Linguistics. 1989;13: 271-309.

17. Исаченко АВ. К вопросу о периодизации истории русского языка. В: Маслов ЮС, редактор. Вопросы теории и истории языка. Сборник в честь профессора Б. А. Ларина. Ленинград: Издательство Ленинградского университета; 1963. с. $149-158$.

18. Яскевіч АА, укладальнік. Старабеларускія лексіконы («Лексисъ съ толкованіемъ словенскіхъ мовъ просто», «Лексис...» Л. Зізанія, «Синонима славеноросская»). Мінск: Выдавецтва Беларускага дзяржаўнага уиніверсітэта; 1992. $174 \mathrm{c}$.

19. Яскевіч АА. «Лексіс з талкаваннем славенскіх моў проста». У: Сачанка БІ, Міхневіч АЯ, рэдактары. Беларуская мова: энцыклапедыя. Мінск: Беларуская Энцыклапедыя; 1994. с. 300-301.

20. Берков ВП. Норвежский язык. В: Ярцева В, Солнцев В, Толстой Н, редакторы. Языки мира. Германские языки. Кельтские языки. Москва: Асаdemia; 2000. с. 300-327.

21. Стеблин-Каменский МИ. Образование норвежского национального языка. Вопросы языкознания. 1952;1:107-120.

22. Стеблин-Каменский МИ. История скандинавских языков. Москва: Издательство Академии Наук СССР; 1953.340 с.

23. Беликов ВИ, Крысин ЛП, редакторы. Социолингвистика. Москва: Российский государственный гуманитарный университет; 2001. 315 с.

24. Михальченко ВЮ, редактор. Словарь социолингвистических терминов. Москва: Институт языкознания РАН; 2006. 312 с.

25. Петренко ВД, Петренко ДА. Билингвизм и вариативность языкового репертуара билингва. Иностранные языки в высшей школе. 2018;4:42-55.

26. Хауген Э. Языковой контакт. В: Розенцвейг ВЮ, редактор. Новое в лингвистие. Выпуск 6. Языковые контакты. Москва: Прогресс; 1972. с. 61-80.

27. Rodriguez I. Towards an understanding on the ideological effects of contact-induced phenomena in the Basque Country. In: Kohlberger M, Kloekhorst A, editors. $48^{\text {th }}$ Annual meeting of the Societas Linguistica Europaea; 2015 September 2-5; Leiden, Netherlands. Book of abstracts. Leiden: Leiden University Centre for Linguistics; 2015. p. 132-133.

28. Шейгал ЕИ. Семиотика политического дискурса. Москва: Гнозис; 2004. 324 с.

29. Walsby H. The domain of ideologies: a study of the origins development and structure of ideologies. Portland: 127 House; 2020. 250 p.

30. Иванова МЕ. Язык идеологии и идеология языка: аспекты взаимодействия. Манускрипт. 2020;13(1):133-140. DOI: 10.30853/manuscript.2020.1.27.

31. Walford G. Beyond politics: an outline of systematic ideology. London: Calabria Press; 1990.190 p.

32. Marín-Arrese JI. Effective control in political discourse: a cross-linguistic study of text-related variation. In: Kohlberger M, Kloekhorst A, editors. $48^{\text {th }}$ Annual meeting of the Societas Linguistica Europaea; 2015 September 2-5; Leiden, Netherlands. Book of abstracts. Leiden: Leiden University Centre for Linguistics; 2015. p. 105-106.

33. Lestrade S. Simulating the development of argument marking. In: Kohlberger M, Kloekhorst A, editors. $48^{\text {th }}$ Annual meeting of the Societas Linguistica Europaea; 2015 September 2-5; Leiden, Netherlands. Book of abstracts. Leiden: Leiden University Centre for Linguistics; 2015. p. 92.

34. Ferguson CA. The ethiopian language area. In: Bender ML, Bowen JD, Cooper RL, Ferguson CA, editors. Language in Ethiopia. Oxford: Oxford University Press; 1976. p. 63-76.

35. Голикова ТА. Введение в языкознание. Москва: Directmedia; 2016. 369 с.

36. Diebold AR. The consequences of early bilingualism in cognitive development and personality formation. In: Titone R, editor. On the bilingual person. Canadian society for Italian studies. [S. 1.]: Biblioteca di Quaderni d'italianistica; 1989. p. 65-92.

37. Cummins J. Bilingual education: basic principles. In: Dewaele JM, Housen A, Wei L, editors. Bilingualism: beyond basic principles. Festschrift in honour of Hugo Baetens Beardsmore. Clevedon: Multilingual Matters; 2003. p. 56-67. 
38. [Лёсік Я]. Да рэформы беларускай азбукі [даклад у рамках секцыі]. У: Некрашэвіч С, Ігнатоўскі У, рэдактары. Працы Акадэмічнае канфэрэнцыі па рэформе беларускага правапісу і азбукі; 14-21 лістапада 1926 г.; Мінск, БССР. Мінск: Інстытут беларускае культуры; 1927. с. 115-123.

39. Лыч ЛМ. Духоўны дыямент нацыі: мова як аб’ект дзяржаўнай палітыкі. Беларуская думка. 2014;8:52-58.

40. Виноградов ВА. Языковая ситуация [Интернет]. В: Ярцева ВН, редактор. Лингвистический энциклопедический словарь. Москва: Советская энциклопедия; 1990 [процитировано 2 июля 2020 г.]. Доступно по: http://tapemark.narod. $\mathrm{ru} / \mathrm{les} / 616 \mathrm{~b} . \mathrm{html}$.

41. Аврорин ВА. Проблемы изучения функциональной стороны языка. К вопросу о предмете социолингвистики. Ленинград: Наука; 1975. с. 124-148.

42. Алпатов ВМ. История одного мифа: Марр и марризм. Москва: Editorial URSS; 2011. 288 с.

43. Башинджагян ЛГ. Институт мышления и языка имени Н. Я. Марра. Вестник Академии наук СССР. 1937; $10-11: 251-265$.

44. Дешериев ЮД. Языковые проблемы многонационального советского общества. Вопросы языкознания. $1982 ; 6: 14-27$.

45. Иванов ВВ, Михайловская НГ. Русский язык как средство межнационального общения: актуальные аспекты и проблемы. Вопросы языкознания. 1982;6:3-13.

46. Алпатов ВМ. Языковая ситуация в регионах современной России. Отечественные записки [Интернет]. 2005 [процитировано 2 июля 2020 г.];2:210-219. Доступно по: https://strana-oz.ru/2005/2/yazykovaya-situaciya-v-regionahsovremennoy-rossii.

47. Мальдзіс АІ. На скрыжаванні славянскіх традыцый. Літаратура Беларусі пераходнага перыяду (другая палавіна XVII - XVIII cm.). Мінск: Навука і тэхніка; 1980. 352 с.

48. Behaghel O. Geschichte der deutschen Sprache. Berlin: Walter de Gruyter; 1928. 588 S.

49. Баліцкі А. Беларусізацыя культурна-асьветных устаноў. Полымя. 1925;4:117-148.

50. Barker GC. Social functions of language in a Mexican-American community. Acta Americana. 1947;5:185-202.

51. Barker GC. Growing up in a bilingual community. The Kiva. 1951;17:17-32.

52. Barker GC. Pachuco: an American-Spanish argot and its social functions in Tucson, Arizona [Internet]. University of Arizona Social Science Bulletin. 1950 [cited 2020 July 29];18(1). Available from: https://repository.arizona.edu/ handle/10150/632299.

53. Сомин АА. Языковая рефлексия в современной Беларуси сквозь призму комментариев в интернет-СМИ. Вестник Российского государственного гуманитарного университета. Серия: Литературоведение. Языкознание. Культурология. 2015;1:62-86.

54. Кобенко ЮВ. Экзоглоссная и эндоглоссная фазы языковой эволюции. Вестник Вятского государственного университета. Филология и искусствоведение. 2010;4(2):56-59.

55. Нурлигенова 3Н, Джумабаева КА, Серкжан БМ. Реализация культурного проекта «Триединства языка» в Республике Казахстан. В: Вострецов АИ, редактор. Достижения современной науки: от теории к практике. Материалы научно-практической (заочной) конференции; 28 ноября 2019; Минск, Беларусь. Нефтекамск: Научно-издательский центр «Мир науки»; 2019. с. 53-58.

56. Суюнбаева АЖ. Языковая ситуация как фактор функционирования языка для специальных целей. Научный диалог. 2016;5:97-108.

57. Жаркынбекова ШК. Языковые трансформации в новых геополитических условиях Казахстана (социолингвистический анализ). В: Вербицкая ЛА, Рогова КА, Попова ТИ, редакторы. Русский язык и литература в пространстве мировой культуры. Материалы ХІІІ конгресса МАПРЯЛ - Международной ассоциации преподавателей русского языка и литературы; 13-20 сентября 2015; Гранада, Испания. Том 2. Санкт-Петербург: МАПРяЛ; 2015. с. 54-59.

58. О’Бикен Д. «Казахизация» и языковая политика в постсоветском Казахстане. В: Киселев КВ, редактор. Политическая наука и государственная власть в Российской Федерации и новых независимых государствах. Екатеринбург: Уральское отделение РАН; 2005. с. 68-84.

59. O’Beacháin D, Kevlihan R. State-building, identity and nationalism in Kazakhstan: some preliminary thoughts. Working Papers in International Studies (Centre for International Studies of Dublin City University). 2011;1:1-18.

60. Matuszkiewicz R. The language issue in Kazakhstan - institutionalizing new ethnic relations after independence. Economic and Environmental Studies. 2010;10(2):211-227.

61. Cummings SN. Power and change in Central Asia. London: Routledge; 2002. 158 p. (Politics in Asia). DOI: 10.4324/ 9780203166918.

62. Щерба ЛВ. К вопросу о двуязычии. В: Щерба ЛВ. Языковая система и речевая деятельность. Ленинград: Наука; 1974. c. $313-318$.

63. Хауген Э. Лингвистика и языковое планирование. В: Чемоданов НС, редактор. Новое в лингвистике. Bыпуск 7. Социолингвистика. Москва: Прогресс; 1975. с. 441-472.

64. Бодуэн де Куртэнэ АИ. Вспомогательный международный язык. В: Бодуэн де Куртэнэ АИ. Избранные труды по общему языкознанию. Том 2. Москва: Издательство АН СССР; 1963. с. 144-160.

65. Fishman JA, Gertner MH, editors. The rise and fall of the ethnic revival: perspectives on language and ethnicity. Berlin: Walter de Gruyter; 1985.531 p. (Contributions to the Sociology of Language).

66. Исаев МИ. Е. А. Бокарев и интралингвистика. В: Исаев МИ, редактор. Проблемы интерлингвистики типология и эволюция международных искусственных языков. Москва: Наука; 1976. с. 5-11.

67. Некрашэвіч С, Ігнатоўскі У, рэдактары. Працы Акадэмічнае канфэрэнщыі па рэформе беларускага правапісу і азбукі; 14-21 лістапада 1926 г.; Мінск, БССР. Мінск: Інстытут беларускае культуры; 1927. 431 с.

68. Edwards J. Multilingualism: understanding linguistic diversity. London: Routledge; 2012.134 p.

69. Скворцов ЛИ. Культура речи [Интернет]. В: Ярцева ВН, редактор. Лингвистический энциклопедический словарь. Москва: Советская энциклопедия; 1990 [процитировано 16 июля 2020 г.]. Доступно по: http://tapemark.narod.ru/ les/247a.html. 
70. Иванов ВячВс. Древнеиндийский миф об установлении имен и его параллель в греческой традиции. В: Струве ВВ, Бонгард-Левин ГМ, редакторы. Индия в древности. Москва: Наука: 1964. с. 85-94.

71. Вайнрайх У. Одноязычие и многоязычие. В: Розенцвейг ВЮ, редактор. Новое в лингвистике. Выпуск 6. Языковые контакты. Москва: Прогресс; 1972. с. 25-61.

72. Лукашанец А. Беларуская мова ў пачатку XXI ст. Веснік Беларускага дзяржаўнага ўніверсітэта. Серыя 4. Філалогія. Журналістыка. Педагогіка. 2009;1:4-10.

73. Лукашанец АА. Беларуская мова ў XXI ст.: асаблівасці развіцця і функцыянавання. У: Беларускі дзяржаўны ўніверсітэт. Мова - Літаратура - Культура. Матэрыялы VI Міжнароднай навуковай канферэнцыі; 28-29 кастрычніка 2010 г.; Мінск, Беларусь. Частка 1. Мінск: РІВШ; 2011. с. 3-8.

\section{References}

1. Edwards J. Foundations of Bilingualism. In: Bhatia TK, Ritchie WC, editors. The handbook of bilingualism. Malden: Blackwell; 2006. p. 7-31.

2. Baker C. Foundations of bilingual education and bilingualism. Clevedon: Multilingual Matters Ltd.; 1993. 492 p.

3. Zhirmunsky VM. Natsional'nyi yazyk $i$ sotsial'nye dialekty [National language and social dialects]. Leningrad: Khudozhestvennaya literatura; 1936. 304 p. Russian.

4. Yartseva VN. [The theory of language interaction and the work of U. Weinreich «Language contacts»]. In: Weinreich U. Yazykovye kontakty. Sostoyanie i problemy issledovaniya [Language contacts. Research status and problems]. Blagoveshchensk: BGK imeni I. A. Boduena de Kurtene; 2000. p. 5-17. Russian.

5. Hertzler JO. A Sociology o flanguage. New York: Random House; 1965.559 p.

6. Weinreich U. Yazykovye kontakty. Sostoyanie i problemy issledovaniya [Language contacts. Research status and problems]. Blagoveshchensk: BGK imeni I. A. Boduena de Kurtene; 2000. 264 p. Russian.

7. Peterson MN. [Language as a social phenomenon]. Uchenye zapiski Instituta yazyka i literatury. 1927;1:3-21. Russian.

8. Hadson U. Diglossia. In: Spolsky B, editor. Concise encyclopaedia of educational linguistics. Oxford: Elsever Science Ltd.; 1999. p. 37-42.

9. Baudouin de Courtenay JI. [The mixed nature of all languages]. In: Baudouin de Courtenay JI. Izbrannye trudy po obshchemu yazykoznaniyu. Tom 1 [Selected works on general linguistics. Volume 1]. Moscow: Publishing House of the Academy of Sciences of the USSR; 1963. p. 362-372. Russian.

10. Baudouin de Courtenay JI. [Language and languages]. In: Baudouin de Courtenay JI. Izbrannye trudy po obshchemu yazykoznaniyu. Tom 2 [Selected works on general linguistics. Volume 2]. Moscow: Publishing House of the Academy of Sciences of the USSR; 1963. p. 67-95. Russian.

11. Ferguson ChA. Diglossia. World. 1959;15(2):325-340.

12. Ferguson ChA. [Problems of the influence of the language situation on teaching a second language]. In: Neroznak VP, compiler; Gak VG, editor. Novoe v zarubezhnoi lingvistike. Vypusk 25. Kontrastivnaya lingvistika: perevody [New in foreign linguistics. Issue 25. Contrastive linguistics: translations]. Moscow: Progress; 1989. p. 122-127. Russian.

13. Ferguson ChA. The phonems of Bengali. Language. 1962;36:22-59.

14. Mechkovskaya NB. Sotsial'naya lingvistika [Social linguistics]. Moscow: Aspekt Press; 1996. 207 p. Russian.

15. Krysin LP. [Tenure of various subsystems of the language as a phenomenon of diglossia]. In: Krysin LP. Russkoe slovo, svoe i chuzhoe. Issledovaniya po sovremennomu russkomu yazyku i sotsiolingvistike [The Russian word, one's own and someone else's. Studies in modern Russian language and sociolinguistics]. Moscow: Yazyki slavyanskoi kul'tury; 2004. p. 468-474. Russian.

16. Shapir MI. [The theory of «Church-Slavonic - Russian diglossia» and its supporters]. Russian Linguistics. 1989;13(2): 271-309. Russian.

17. Isachenko AV. [On the question of the periodization of the history of the Russian language]. In: Maslov YuS, editor. Voprosy teorii $i$ istorii yazyka. Sbornik $v$ chest' professora B. A. Larina [Questions of the theory and history of language. A collection in honor of professor B. A. Larin]. Leningrad: Publishing House of the Leningrad University; 1963.341 p. $149-$ 158. Russian.

18. Yaskevich AA, compiler. Starabelaruskija leksikony («Leksis s tolkovaniem slovenskikh mov prosto», «Leksis...»L. Zizanija, «Sinonima slavenorosskaya») [Old Belarusian lexicons («Lexis with the interpretation of Slovenian languages simply», «Lexis...» by L. Zizany, «Synonyma of Slavonic»)]. Minsk: Belarusian State University Publishing House; 1992.174 p. Belarusian.

19. Yaskevich AA. [Lexis with the interpretation of Slovenian languages simply]. In: Sachanka BI, Mikhnevich AYa, editors. Belaruskaja mova: jencyklapedyja [Belarusian language: encyclopedia]. Minsk: Belaruskaja jencyklapedyja; 1994. p. 300-301. Belarusian.

20. Berkov VP. [Norwegian language]. In: Yartseva V, Solntsev V, Tolstoi N, editors. Yazyki mira. Germanskie yazyki. Kel'tskie yazyki [Languages of the World: Germanic Languages. Celtic languages]. Moscow: Academia; 2000. p. 300-327. Russian.

21. Steblin-Kamensky MI. [The emergence of the Norwegian national language]. Voprosy yazykoznaniya. 1952;1:107-120.

22. Steblin-Kamensky MI. Istoriya skandinavskikh yazykov [History of the Scandinavian languages]. Moscow: USSR Academy of Sciences Publishing House; 1953. 340 p. Russian.

23. Belikov VI, Krysin LP, editors. Sotsiolingvistika [Sociolinguistics]. Moscow: Russian State University for the Humanities; 2001. 315 p. Russian.

24. Mikhalchenko VYu, editor. Slovar' sotsiolingvisticheskikh terminov [Dictionary of sociolinguistic terms]. Moscow: Institute of Linguistics of Russian Akadamy of Sciences; 2006. 312 p. Russian.

25. Petrenko VD, Petrenko DA. Bilingualism and variability of the bilingual's repertoire language. Inostrannye yazyki $v$ vysshei shkole. $2018 ; 4: 42-55$. Russian.

26. Haugen E. [Language contact]. In: Rosenzweig VYu, editor. Novoe v lingvistie. Vypusk 6. Yazykovye kontakty [New in linguistics. Issue 6. Language contacts]. Moscow: Progress; 1972. p. 61-80. Russian. 
27. Rodriguez I. Towards an understanding on the ideological effects of contact-induced phenomena in the Basque Country. In: Kohlberger M, Kloekhorst A, editors. $48^{\text {th }}$ Annual meeting of the Societas Linguistica Europaea; 2015 September 2-5; Leiden, Netherlands. Book of abstracts. Leiden: Leiden University Centre for Linguistics; 2015. p. 132-133.

28. Sheigal EI. Semiotika politicheskogo diskursa [Semiotics of the Political Discourse]. Moscow: Gnosis; 2004.324 p. Russian.

29. Walsby H. The domain of ideologies: a study of the origins development and structure of ideologies. Portland: 127 House; 2020. 250 p.

30. Ivanova ME. Language of ideology and ideology of language: aspects of interaction. Manuscript. 2020;13(1):133-140. Russian. DOI: 10.30853/manuscript.2020.1.27.

31. Walford G. Beyond politics: an outline of systematic ideology. London: Calabria Press; 1990.190 p.

32. Marín-Arrese JI. Effective control in political discourse: a cross-linguistic study of text-related variation. In: Kohlberger M, Kloekhorst A, editors. 48 ${ }^{\text {th }}$ Annual meeting of the Societas Linguistica Europaea; 2015 September 2-5; Leiden, Netherlands. Book of abstracts. Leiden: Leiden University Centre for Linguistics; 2015. p. 105-106.

33. Lestrade S. Simulating the development of argument marking. In: Kohlberger M, Kloekhorst A, editors. $48^{\text {th }}$ Annual meeting of the Societas Linguistica Europaea; 2015 September 2-5; Leiden, Netherlands. Book of abstracts. Leiden: Leiden University Centre for Linguistics; 2015. p. 92.

34. Ferguson CA. The ethiopian language area. In: Bender ML, Bowen JD, Cooper RL, Ferguson CA, editors. Language in Ethiopia. Oxford: Oxford University Press; 1976. p. 63-76.

35. Golikova TA. Vvedenie v yazykoznanie [Introduction to linguistics]. Moscow: Directmedia; 2016. 369 p. Russian.

36. Diebold AR. The consequences of early bilingualism in cognitive development and personality formation. In: Titone R, editor. On the bilingual person. Canadian society for Italian studies. [S. 1.]: Biblioteca di Quaderni d'italianistica; 1989. p. 65-92.

37. Cummins J. Bilingual education: basic principles. In: Dewaele JM, Housen A, Wei L, editors. Bilingualism: beyond basic principles. Festschrift in honour of Hugo Baetens Beardsmore. Clevedon: Multilingual Matters; 2003. p. 56-67.

38. [Liosik Ja]. [Towards the reform of the Belarusian alphabet (report within the discussion)]. In: Nekrashevich S, Ihnatouski V, editors. Pracy Akadjemichnae kanfjerjencyi pa rjeforme belaruskaga pravapisu i azbuki; 14-21 listapada 1926 g.; Minsk, BSSR [Proceedings of the Academic Conference on the Reform of the Belarusian Spelling and Alphabet; 1926 November 14-21; Minsk, BSSR]. Minsk: Institute of Belarusian Culture; 1927. p. 115-123. Belarusian.

39. Lych LM. [The spiritual diamond of the nation: language as an object of state policy]. Belaruskaja dumka. 2014;8: 52-58. Belarusian.

40. Vinogradov VA. Language situation [Internet]. In: Yartseva VN, editor. Lingvisticheskii entsiklopedicheskii slovar [Linguistic encyclopedic dictionary]. Moscow: Sovetskaya entsyclopediya; 1990 [cited 2020 July 2]. Available from: http:// tapemark.narod.ru/les/616b.html. Russian.

41. Aurorin VA. Problemy izucheniya funktsional'noi storony yazyka. K voprosu o predmete sotsiolingvistiki [Problems of studying the functional side of language. On the subject of sociolinguistics]. Leningrad: Nauka; 1975. p. 124-148. Russian.

42. Alpatov VM. Istoriya odnogo mifa: Marr i marrizm [The history of one myth: Marr and Marrism]. Moscow: Editorial URSS; 2011. 288 p. Russian.

43. Bashinjaghyan LG. [Institute of Thinking and Language named after N.Ya. Marr]. Vestnik Akademii nauk SSSR. 1937; 10-11:251-265. Russian.

44. Desheriev YuD. Linguistic problems of the multinational Soviet society. Voprosy yazykoznaniya. 1982;6:14-27. Russian. 45. Ivanov VV, Mixajlovskaja NG. The Russian language as a means of communication among nations. Voprosy yazykoznaniya. 1982;6:3-13. Russian.

46. Alpatov VM. [The language situation in the regions of modern Russia]. Otechestvennye zapiski [Internet]. 2005 [cited 2020 July 2];2:210-219. Available from: https://strana-oz.ru/2005/2/yazykovaya-situaciya-v-regionah-sovremennoy-rossii. Russian.

47. Maldzis AI. Na skryzhavanni slavjanskih tradycyj. Litaratura Belarusi perahodnaga peryjadu (drugaja palavina XVII - XVIII st.) [At the crossroads of Slavic traditions. Literature of Belarus in the transition period (second half of the $17^{\text {th }}-18^{\text {th }}$ centuries)]. Minsk: Navuka i tehnika; 1980.352 p. Belarusian.

48. Behaghel O. Geschichte der deutschen Sprache. Berlin: Walter de Gruyter; 1928. 588 S.

49. Balitsky A. [Belarusianization of cultural and educational institutions]. Polymja. 1925;4:117-148. Belarusian.

50. Barker GC. Social functions of language in a Mexican-American community. Acta Americana. 1947;5:185-202.

51. Barker GC. Growing up in a bilingual community. The Kiva. 1951;17:17-32.

52. Barker GC. Pachuco: an American-Spanish argot and its social functions in Tucson, Arizona [Internet]. University of Arizona Social Science Bulletin. 1950 [cited 2020 July 29];18(1). Available from: https://repository.arizona.edu/ handle/10150/632299.

53. Somin A. Attitudes to the belarusian language through the prism of comments in the online media. RSUH/RGGU Bulletin: Literary Teory. Linguistics. Cultural Studies Series. 2015;1:62-86. Russian.

54. Kobenko YuV. Exo- and endoglossic phases of linguistic evolution. Vestnik Vyatskogo gosudarstvennogo universiteta. Filologiya i iskusstvovedenie. 2010;4(2):56-59. Russian.

55. Nurligenova ZN, Dzhumabayeva KA, Serikzhan BM. [Implementation of the cultural project «Language Trinity» in the Republic of Kazakhstan]. In: Vostretsov AI, editor. Dostizheniya sovremennoi nauki: ot teorii k praktike. Materialy nauchno-prakticheskoi (zaochnoi) konferentsii; 28 noyabrya 2019; Minsk, Belarus' [Achievements of modern science: from theory to practice. Materials of a scientific-practical conference; 2019 November 28; Minsk, Belarus]. Neftekamsk: Scientific Publishing Center «Mir nauki»; 2019. p. 53-58. Russian.

56. Suyunbaeva A. Zh. [Language situation as a factor of language functioning for special purposes]. Nauchnyi dialog. 2016;5:97-108. Russian.

57. Zharkynbekova ShK. [Language transformations in the new geopolitical conditions of Kazakhstan (sociolinguistic analysis)]. In: Verbitskaya LA, Rogova KA, Popova TI, editors. Russkii yazyk i literatura v prostranstve mirovoi kul'tury: Materialy XIII Kongressa MAPRYaL - Mezhdunarodnoi assotsiatsii prepodavatelei russkogo yazyka i literatury; 13-20 sentyabrya 2015; Granada, Ispaniya. Tom 2 [Russian language and literature in the space of world culture: Proceedings of the XIII Congress of 
International Association of Teachers of Russian Language and Literature; 2015 September 13-20; Granada, Spain. Volume 2]. Saint Petersburg: International Association of Teachers of Russian Language and Literature; 2015. p. 54-59. Russian.

58. O’Beacháin D. [«Kazakhization» and language policy in post-Soviet Kazakhstan]. In: Kiselev KV, editor. Politicheskaya nauka i gosudarstvennaya vlast'v Rossiiskoi Federatsii i novykh nezavisimykh gosudarstvakh [Political science and state power in the Russian Federation and Newly Independent States]. Ekaterinburg: Ural Branch of the Russian Academy of Sciences: 2005. p. 68-84. Russian.

59. O’Beacháin D, Kevlihan R. State-building, identity and nationalism in Kazakhstan: some preliminary thoughts. Working Papers in International Studies (Centre for International Studies of Dublin City University). 2011;1:1-18.

60. Matuszkiewicz R. The language issue in Kazakhstan - institutionalizing new ethnic relations after independence. Economic and Environmental Studies. 2010;10(2):211-227.

61. Cummings SN. Power and change in Central Asia. London: Routledge; 2002. 158 p. (Politics in Asia). DOI: 10.4324/ 9780203166918.

62. Shcherba LV. [On the issue of bilingualism]. In: Shcherba LV. Yazykovaya sistema i rechevaya deyatel'nost' [Language system and speech activity]. Leningrad: Nauka; 1974.p. 313-318. Russian.

63. Haugen E. [Linguistics and language planning]. In: Chemodanov NS, editor. Novoe v lingvistike. Vypusk 7. Sotsiolingvistika [New in linguistics. Issue 7. Sociolinguistics]. Moscow: Progress; 1975. p. 441-472. Russian.

64. Baudouin de Courtenay JI. [Auxiliary international language]. In: Baudouin de Courtenay JI. Izbrannye trudy po obshchemu yazykoznaniyu. Tom 2 [Selected works on general linguistics. Volume 2]. Moscow: Publishing house of the Academy of Sciences of the USSR; 1963. p. 144-160. Russian.

65. Fishman JA, Gertner MH, editors. The rise and fall of the ethnic revival: perspectives on language and ethnicity. Berlin: Walter de Gruyter; 1985.531 p. (Contributions to the Sociology of Language).

66. Isaev MI. [E. A. Bokarev and intralinguistics]. In: Isaev MI, editor. Problemy interlingvistiki tipologiya i evolyutsiya mezhdunarodnykh iskusstvennykh yazykov [Problems of interlinguistics, typology and evolution of international artificial languages]. Moscow: Nauka; 1976. p. 5-11. Russian.

67. Nekrashevich S, Ihnatouski V, editors. Pracy Akadjemichnae kanfjerjencyi pa rjeforme belaruskaga pravapisu i azbuki; 14-21 listapada 1926 g.; Minsk, BSSR [Proceedings of the Academic Conference on the Reform of the Belarusian Spelling and Alphabet; 1926 November 14-21; Minsk, BSSR]. Minsk: Institute of Belarusian Culture; 1927. 431 p. Belarusian.

68. Edwards J. Multilingualism: understanding linguistic diversity. London: Routledge; 2012.134 p.

69. Skvortsov LI. A culture of speech [Internet]. In: Yartseva VN, editor. Lingvisticheskii entsiklopedicheskii slovar' [Linguistic encyclopedic dictionary]. Moscow: Sovetslaya Entsyklopediya; 1990 [2020 cited July 16]. Available from: http://tapemark. narod.ru/les/247a.html. Russian.

70. Ivanov VV. [The ancient Indian myth of the establishment of names and its parallel in the Greek tradition]. In: Struve VV, Bongard-Levin GM, editors. Indiya $v$ drevnosti [India in Antiquity]. Moscow: Nauka; 1964. p. 85-94. Russian.

71. Weinreich U. [Monolingualism and multilingualism]. In: Rosenzweig VYu, editor. Novoe v lingvistike. Vypusk 6. Yazykovye kontakty [New in linguistics. Issue 6. Language contacts]. Moscow: Progress; 1972. p. 25-61. Russian.

72. Lukashanets A. Belarusian language at the beginning of the XXI century. Vesnik Belaruskaga dzjarzhawnaga wniversitjeta. Seryja 4. Filalogija. Zhurnalistyka. Pedagogika. 2009;1:4-10. Belarusian.

73. Lukashanets A. [Belarusian language in the $21^{\text {st }}$ century: features of development and functioning]. In: Belarusian State University. Mova - Litaratura - Kul'tura. Matjeryjaly VI Mizhnarodnaj navukovaj kanferjencyi; 28-29 kastrychnika 2010 g.; Minsk, Belarus'. Chastka 1 [Language - Literature - Culture. Proceedings of the $6^{\text {th }}$ International Scientific Conference; 2010 October 28-29; Minsk, Belarus. Part 1]. Minsk: Republican Institute of Higher Education; 2011. p. 3-8. Belarusian. 